\title{
Pelatihan Pemasaran dan Labeling pada Usaha Jajan Laklak di Denpasar
}

\author{
I Gede Suardika', Made Dewi Ayu Untari², Nyoman Ayu Nila Dewi ${ }^{3}$ \\ 1,2,3STIKOM Bali \\ email: 1suardika@stikom-bali.ac.id, 2yuniantaristikom20@gmail.com, 3nila@stikom-bali.ac.id
}

\begin{abstract}
Abstrak
Bali merupakan salah satu kota yang memiliki beraneka macam masakan dan makanan khas. Jajanan tradisional di Bali mulai dari jajan sangait, klepon, laklak, pisang rai, dan masih banyak lagi lainnya saat ini menjadi makanan yang sangat digemari oleh masyarakat. Seperti halnya kini banyak ditemui jajan tradisional laklak Bali yang memiliki bahan dasar tepung terigu, santan dan kepala parut. Industri rumah tangga jajan laklak Bali yang menjadi mitra dalam kegiatan ini adalah Ibu Sri yang memiliki aktivitas untuk memproduksi jajan tradisional yang telah diproduksi dari tahun 1990an. Mitra dalam kegiatan pengabdian ini memiliki kendala untuk memasarkan dan mengenalkan hasil karya jajan yang diproduksi, dimana jajan tradisional yang ada saat ini hanya diproduksi dan dijual di sekitaran rumah. Terkadang beberapa pembeli datang langsung ke tempat produksi yakni di rumah mitra. Melihat hal tersebut dalam kegiatan pengabdian masyarakat ini akan diberikan suatu pelatihan media pemasaran agar mitra dapat memasarkan jajanan yang telah diproduksi. Kegiatan pengabdian masyarakat ini memberikan pelatihan media pemasaran dimana pemasaran yang dilakukan yaitu dengan memberikan pelatihan media sosial seperti instagram, dan media sosial lainnya.
\end{abstract}

Kata Kunci: pelatihan,pemasaran, jajanan tradisional

\section{Abstract}

Bali is a city that has a variety of specialties and cuisines. Traditional snacks in Bali, ranging from jajan sangait, klepon, laklak, pisang rai, and many others, are today very popular with the people. As is the case today, there are many traditional Balinese laklak snacks which have the basic ingredients of wheat flour, coconut milk and grated heads. The home industry of Balinese laklak snacks which is a partner in this activity is Mrs. Sri, who has activities to produce traditional snacks that have been produced since the 1990s. Partners in this service activity have a shop to market and introduce the work of snacks that are produced, where the current traditional snacks are only produced and sold around the house. Sometimes buyers come directly to the place of production, namely at the partner's house. Seeing this in this community service activity, a marketing media training will be given so that partners can market the snacks that have been produced. Community service activities provide media marketing training where marketing is carried out by providing social media training such as Instagram and other social media.

Keywords: training, marketing, traditional snacks 


\section{Pendahuluan}

Bali merupakan salah satu provinsi di Indonesia yang memiliki aneka macam jajanan khas. Bersumber pada budaya lokal (local indigenous), makanan tradisional memiliki nilai budaya, tradisi, serta kepercayaan (Ernayanti et al., 2003). Seperti halnya jajan klepon, jajan sangait, jajan pisang rai, jajan laklak dan masih banyak jajanan lain yang terdapat di Bali. Setiap kabupaten memiliki jajanan khas masing-masing. Jajanan merupakan makanan tradisional yang biasa dimakan sehari-hari namun bukan sebagai makanan pokok (Huda, 2018). Dalam kegiatan pengabdian masyarakat ini akan mengangkat jajanan tradisional Bali yaitu jajan laklak Bali. Jajanan tradisonal saat ini mulai digemari kembali oleh masyarakat (Nata et al., 2018), biasanya jajanan tradisional hanya digunakan pada saat upacara keagamaan khususnya bagi umat Hindu (Ekayanti et al., 2018), jajan laklak masih jarang dipasarkan ke kota-kota, dikarenakan jajanan tradisional identik dengan desa. Jajan laklak tebuat dari bahan dasar tepung terigu, santan, dan kelapa parut, gula merah, serta daun pandan. Golongan menengah ke bawah masih menggemari makanan jajanan yang diperjualbelikan di pasar tradisional (Supraptini et al., 2011). Saat ini jajan laklak Bali menjadi kegemaran masyarakat dimana rasanya yang gurih serta manis dengan tambahan gula aren. Jajan laklak juga dipakai oleh Puri Kerambitan di Bali untuk memperkenalkan wisatawan terhadap kehidupan pedesaan terutama tentang pengolahan makanan tradisional (RUASTITI, 2011).

Mitra dalam kegiatan ini adalah Ibu Sri yang sudah menekuni pekerjaan ini sejak tahun 1990, dimana pekerjaan ini telah dikerjakan dan dibantu oleh keluarga untuk proses produksi. Lokasi mitra berada di Denpasar, jarak lokasi mitra dengan pengusul sekitar $10 \mathrm{~km}$ dapat ditempuh dengan kendaraan roda dua maupun roda empat. Aktivitas saat ini yang dilakukan mitra adalah membeli bahan-bahan untuk jajan laklak dan memproduksinya kurang lebih sekitar 2-3 jam setiap harinya. Jajan hanya dipasarkan di rumah mitra saja, hal ini dikarenakan mitra belum berani mencoba untuk menitipkan ke warung-warung atau minimarket terdekat untuk menjaga kualitas jajan tetap baik dikonsumsi dalam waktu lama. Seluruh aktivitas dilakukan di rumah mitra dan dibantu oleh keluarga mitra. Dalam hal ini mitra memiliki kendala dalam proses pemasaran dan pembukuan, karena mitra tidak mengetahui secara pasti keuntungan dan kerugian yang telah didapat. Proses pemasaran mitra sangat minim hal ini disebabkan karena mitra tidak memiliki kemampuan dalam pemasaran. Begitu banyak pesaing yang dapat menyebabkan mitra mengalami sedikit pemasukan.

Dalam kegiatan pengabdian masyarakat ini akan dilakukan kegiatan pelatihan pemasaran pada media sosial untuk usaha mitra. Pelatihan ini akan dilakukan dan disesuaikan dengan kondisi serta waktu mitra.

Terdapat beberapa permasalahan yang ada pada mitra usaha jajan laklak Bali tersebut serta disesuaikan dengan kompetensi tim pengabdian masyarakat yakni dalam bidang teknologi informasi. Permasalahan yang saat ini dihadapi dalam UKM ini adalah: 
1. Bagaimana memberikan suatu pelatihan yang dapat dilakukan oleh mitra untuk memanfaatkan internet secara maksimal sebagai media promosi dan pemasaran jajan laklak?

2. Bagaimana memberikan suatu pelatihan untuk menambah pengetahuan mitra tentang media pemasaran dan teknologi informasi yang dapat digunakan dalam pemasaran hasil jajan laklak?

Berdasarkan permasalahan yang telah dipaparkan di atas maka solusi yang ditawarkan untuk menangani permasalahan yang dialami oleh mitra adalah kegiatan pelatihan pemasaran jajan laklak Bali dengan memanfaatkan teknologi informasi. Kegiatan pelatihan ini dilakukan dengan penyampaian beberapa materi tentang teknologi informasi dan tanya jawab kepada mitra tentang pemahamanya mengenai teknologi informasi. Setelah penyampaian materi maka langkah selanjutnya adalah mendokumentasikan hasil-hasil produksi serta melatih pemasaran produk secara online menggunakan media pemasaran yang telah ada seperti instagram dan Facebook atau media online lainnya.

Tujuan dari kegiatan pengabdian masyarakat ini adalah untuk memberikan pengetahuan kepada masyarakat tetang penggunaan internet yang baik dan bermanfaat untuk media pemasaran usaha. Selain itu tujuan kegiatan ini adalah memberikan pengetahuan masyarakat tentang perkembangan teknologi informasi serta teknik pemasaran melalui media internet.

Manfaat dari kegiatan ini adalah diharapkan dapat membuat pemasaran jajan laklak Bali oleh mitra dapat mengalami peningkatan dan dapat diketahui oleh masyarakat luas.

\section{Metode}

Prioritas permasalahan yang saat ini dialami oleh mitra adalah pemasaran jajan laklak Bali. Dari permasalahan tersebut solusi yang ingin diberikan dari permasalahan yang dihadapi adalah dengan memberikan pelatihan serta pemahaman tentang teknologi informasi dalam penggunaan internet yang baik dan maksimal sebagai media pemasaran online hasil produksi. Motode yang diberikan dalam kegiatan ini berupa memberikan pelatihan kepada pemilik usaha dan dan karyawan pada UKM tersebut.

Prosedur kerja kegiatan pengabdian masyarakat dimulai dengan penyampaian proposal yang melalui proses seleksi untuk penerimaan kegiatan pengabdian masyarakat. Mempersiapkan bahan yang akan dijadikan materi dalam kegiatan ini. Pelaksanaan kegiatan pengabdian masyarakat melibatkan UKM dan anggota UKM. Kegiatan pengabdian masyarkat ini dilaksanakan selama 1 bulan pengerjaan mulai dari proses sosilaisasi persiapan materi, penyampaian materi dan evaluasi materi. 


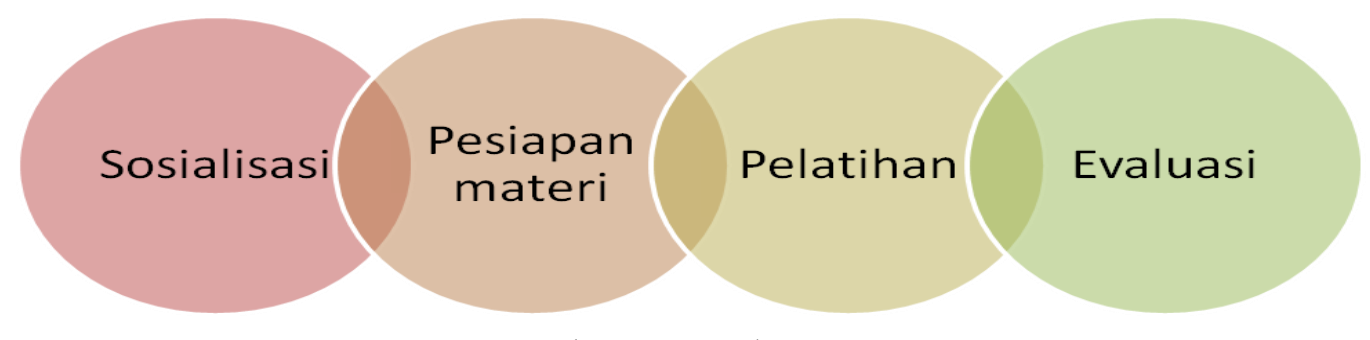

Gambar.1 Prosedur Kerja

Gambar 1 merupakan tahapan dalam rencana kegiatan yang akan dilakukan dalam kegiatan pengabdian masyarakat.

Partisipasi masyarakat dalam kegiatan pengabdian masyarakat ini yakni mitra diharapkan dapat berperan aktif dalam kegiatan tersebut dan dapat memberikan kontribusi diantaranya adalah:

1. UKM mempersiapkan peserta yakni pemilik usaha dan karyawan yang bekerja disana untuk mengikuti pelatihan pemanfaatan media pemasaran online.

2. Peserta berperan aktif dalam proses kegiatan, seperti halnya tanya jawab yang dilakukan pada saat pemberian materi dan peserta dapat langsung mengimplementasikan kegiatan pelatihan, berdiskusi, serta langsung memasarkan hasil produksi.

\section{Hasil dan Pembahasan}

Pada kegiatan pengabdian masyarakat ini, kegiatan pengabdian dilakukan selama kurang lebih 1 bulan. Kegiatan pengabdian masyarakat dilakukan dengan memberikan pelatihan pemasaran untuk produk jajan laklak untuk IRT. Kegiatan pemasaran yang telah dilakukan adalah memberikan pelatihan mengenai labeling kemasan dan pelatihan media sosial untuk penjualan produk yang dihasilkan. Pengemasan adalah kegiatan merancang dan memproduksi wadah atau bungkus sebagai sebuah produk (Kotler \& Keller, 2009). Label dapat menjadi strategi menarik dalam pemasaran (M \& D, 2004), karena label produk pangan menjadi salah satu masukan bagi konsumen (Philipson \& Thomas, 2005). Labeling diberikan kepada mitra karena produk yang dihasilkan belum memiliki label kemasan sebagai informasi mengenai produk yang dijual. Selanjutnya pada kegiatan media sosial untuk pemasaran dilakukan pelatihan pemasaran mengenai jajan laklak dengan pemasaran melalui media instagram. Adapun kegiatan yang di lakukan dimulai dari tahapan sebagai berikut:

Tabel 1. Tahapan Kegiatan

\begin{tabular}{|c|l|l|}
\hline No & \multicolumn{1}{|c|}{ Nama kegiatan } & \multicolumn{1}{c|}{ Waktu pelaksanaan } \\
\hline 1 & $\begin{array}{l}\text { Sosialisasi kegiatan pengabdian } \\
\text { masyarakat }\end{array}$ & 2 jam pelaksanaan \\
\hline 2 & $\begin{array}{l}\text { Pembuatan materi kegiatan pengabdian } \\
\text { masyarakat }\end{array}$ & 4 hari pengerjaan \\
\hline 3 & Pelatihan pemasaran & 2-3 jam pelaksanaan per hari \\
\hline 4 & Pelatihan media sosial & 2 jam pelaksanaan \\
\hline
\end{tabular}




\begin{tabular}{|c|l|l|}
\hline No & \multicolumn{1}{|c|}{ Nama kegiatan } & \multicolumn{1}{c|}{ Waktu pelaksanaan } \\
\hline 5 & Evaluasi kegiatan & $1-2$ jam pelaksanaan \\
\hline 6 & Pembuatan laporan & $\begin{array}{l}\text { Selama masa kerja kegiatan pengabdian } \\
\text { masyarakat }\end{array}$ \\
\hline
\end{tabular}

Kegiatan sosialisasi ini diisi oleh tim kegiaatan pengabdian masyarakat dengan memberikan informasi dan penjelasan mengenai kegiatan yang akan dilakukan, manfaat pemasaran bagi IRT dan penentuan jadwal kegiatan yang akan dilaksanakan. Kegiatan ini dilakukan dengan melakukan kunjungan ke tempat mitra dan melakukan diskusi dengan mitra mengenai kegiatan yang dikerjakan. Kegiatan ini berlangsung selama kurang lebih 2 jam pelaksanaan.

Dalam tahapan pembuatan materi dilakukan penentuan dan pembahasan materi oleh tim pelaksana, dimana mulai dari menentukan label yang akan diberikan kepada mitra, media sosial yang dipilih untuk mitra itu sendiri. Untuk media sosial digunakan Instagram dengan alasan karena pada saat ini banyak pengusaha pengerajin maupun pemilik usaha lainnya melakukan promosi menggunakan instagram dengan respon yang cukup baik (Ramadhan, 2017). Untuk media sosial dari tim mempersiapkan mulai dari pendaftaran sampai dengan aplikasi siap digunakan oleh mitra. Untuk desain label kemasan diberikan sosialisasi manfaat dari label kemasan itu sendiri untuk produk yang dihasilkan. Dimana durasi kegiatan ini berlangsung dalam waktu 4 hari pengerjaan.

Pada tahapan pelatihan pemasaran dilakukan pelatihan pemasaran oleh tim pelaksana kepada mitra dengan melakukan kunjungan ke lokasi mitra memberikan informasi mengenai pelatihan, memberikan pelatihan kepada mitra tentang penggunaan label kemasan. Dalam kegiatan ini dilakukan pelatihan pemasaran dengan memberikan pemasangan label kemasan dan memberikan label kemasan kepada mitra sebanyak 500pcs yang siap digunakan untuk setiap produk yang dihasilkan. Durasi kegiatan ini dilakukan selama 2 jam. Selanjutnya media pemasaran yang dilakukan melalui media sosial adalah tim pelaksana memberikan pelatihan media sosial dengan membuatkan pemasaran kedalam Instagram, dimana mitra melakukan pemasaran produk melalui Instagram. Seluruh informasi produk diperoleh dari mitra. Kegiatan ini berlangsung selama 3 jam pengerjaan. Dalam kegiatan ini dapat dilihat bahwa mitra sangat antusias melakukan kegiatan pengabdian masyarakat, terlihat dari respon mitra saat pelatihan. Mitra merasa sangat terbantu dengan diberikannya pelatihan media sosial dan pemberian label yang diberikan oleh tim. Dengan harapan produk yang baru dirintis oleh tim dapat berkembang.

Tahapan evaluasi dilakukan untuk melihat bagaimana respon mitra setelah mendapatkan pelatihan dari tim pelaksana. Dengan diadakan pelatihan ini selama satu bulan hanya dapat melihat hasil yaitu produk yang dihasilkan telah memiliki label pada setiap kemasan sebagai media pemasaran gratis yang dapat digunakan oleh mitra. Evaluasi selanjutnya dapat dilakukan pada periode selanjutnya pada saat 
melihat perkembangan penjualan mitra. Pemasaran media sosial yang dilakukan untuk saat ini sudah mulai dioptimalkan untuk penggunaannya.

Kegiatan terakhir dalam pengabdian ini adalah pembuatan laporan dimana tim pelaksana membuat laporan pengabdian masyarakat sebagai bukti dan tanggungjawab pengusul terhadap dana dan kegiatan yang telah dilakukan. Kegiatan ini dilakukan oleh pengusul kegiatan pengabdian masyarakat.

Adapun kegiatan pengabdian masyarakat yang telah dihasilkan yaitu pelatihan label kemasan dan media sosial yang telah diberikan sebagai berikut.

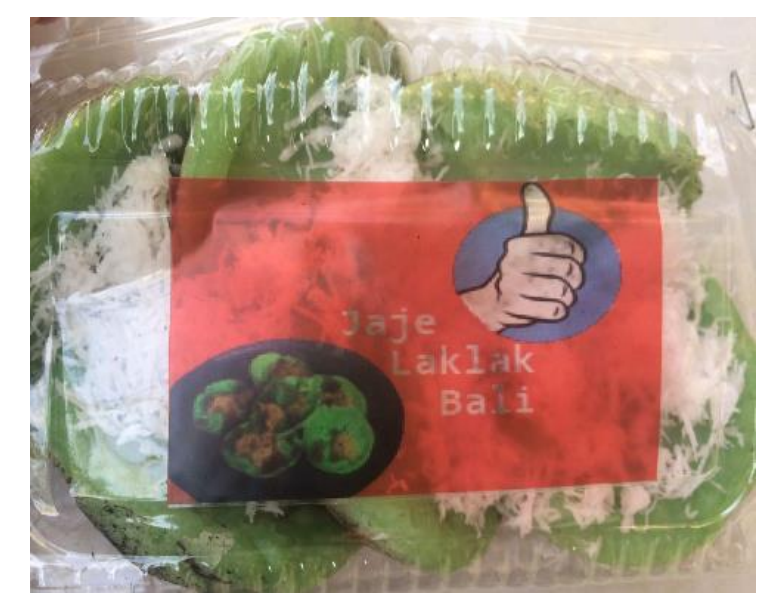

Gambar 2. Produk dengan Label Kemasan

Gambar 2 merupakan hasil produk yang telah diberikan dimana produk yang telah dihasilkan telah diberikan label kemasan dengan desain yang diberikan pada saat pelatihan desain labeling.

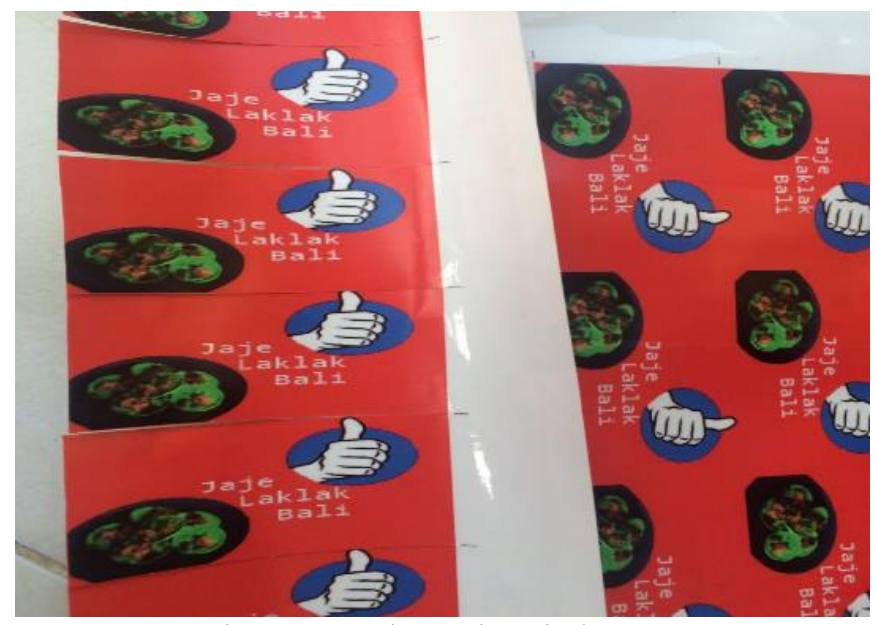

Gambar 3. Hasil Cetak Label Kemasan

Gambar 3 merupakan hasil dari desain label saat pelatihan yang diberikan pada kegiatan pengabdian masyarakat, label yang diberikan merupakan kesepakatan 
dimana informasi desain dan nama label kemasan. Gambar 3 merupakan hasil desain dan hasil cetak labeling kemasan.

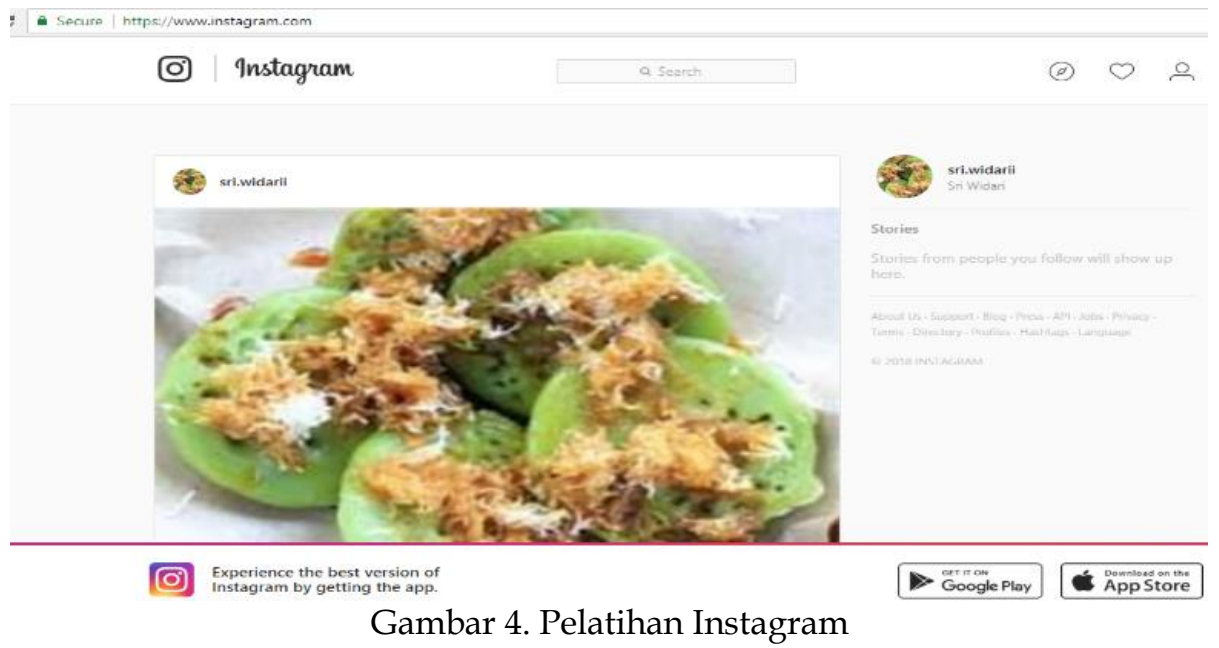

Gambar 4 merupakan hasil pelatihan media sosial dimana pelatihan media sosial yang diberikan dalam pelatihan pengabdian masyarakat ini adalah pelatihan Instagram.

Evaluasi kegiatan pengabdian masyarakat ini dilakukan oleh pengusul ke mitra, hal ini dilakukan untuk mengetahui bagaimana respon dari mitra dalam kegiatan pengabdian masyarakat. Kegiatan pengabdian masyarakat ini mendapat respon yang cukup baik dari mitra. Melalui proses wawancara yang dilakukan setelah melakukan kegiatan pengabdian masyarakat adapun pertanyaan dan kesimpulan jawaban yang dapat dibahas dalam sub bab ini adalah:

1. Apakah kegiatan yang diberikan sangat bermanfaat?

Jawab:

Kesimpulan jawaban yang diberikan oleh mitra dimana mitra cukup puas dengan kegaitan yang diberikan, mitra pun menyatakan bahwa mendapat wawasan baru tentang media sosial yang dilakukan. Karena selama ini mitra tidak mengetahui informasi pemasaran menggunakan Instagram hal ini dikarenakan keterbatasan mitra dalam menggunakan teknologi.

2. Penyampaian materi dapat diterima dengan baik atau tidak? Jawab:

Kesimpulan dari jawaban yang diberikan oleh mitra melalui wawancara yang dilakukan adalah materi mudah diterima namun mitra mengatakan bahwa materi perlu dipelajari kembali dengan perlahan-lahan, dan mitra memberikan pelatihan media sosial kepada anak mitra.

3. Apakah materi dapat dipelajari untuk kedepan nya?

Jawab:

Hasil wawancara menyatakan bahwa kedepan mitra membutuhkan materi pelatihan serupa untuk melakukan perkembangan dalam pemasaran. Hal ini dilakukan agar mitra lebih memahami penggunaan teknologi dan materi pemasaran. 
4. Apakah mitra senang diberikan pelatihan pemasaran?

Jawab:

Kesimpulan dari hasil wawancara menyatakan sangat senang karena dari proses sebelumnya yang tidak memahami pemasaran sekarang lebih mengetahui bagaimana pemasaran dan cara kerja dalam menggunakan teknologi maupun media sosial.

\section{Simpulan dan Rekomendasi}

Kesimpulan dari kegiatan pengabdian ini adalah kegiatan pengabdian masyarakat berjalan cukup lancar dan antusias mitra terhadap kegiatan ini cukup tinggi dilihat dari penyediaan tempat dan peserta pelatihan yang mengikuti kegiatan pengabdian masyarakat. Kegiatan pengabdian ini telah menghasilkan label kemasan untuk produk dan media sosial instagram untuk pemasaran produk yang dihasilkan.

Saran yang dapat diambil untuk kegiatan pengabdian masyarakat ini adalah perlu dilakukan kegiatan serupa dengan mitra untuk dapat dipahami dengan baik oleh mitra. Kegiatan tambahan lainnya yang dapat memberikan bantuan kepada mitra adalah pemberian alat produksi untuk dapat mempermudah dan mempercepat produksi jajan laklak.

\section{Daftar Pustaka}

Ekayanti, Wayan, N., \& Widiadnya, I. B. M. (2018). Ajeg Bali Dengan Jaje Uli: Usaha Mikro Kecil Dan Menengah (UMKM) Kube Cempaka Dan Kelompok Mekar Pembuat Jaje Uli Asli Bali. Majalah Aplikasi Ipteks Ngayah, 9(2), 148-159.

Ernayanti, Silvna, D., \& Sembiring, K. (2003). Ensiklopedi Makanan Tradisional di Pulau Jawa dan Pulau Madura. In Deputi bidang pelestarian dan pengembangan kebudayaan, asdep. Urusan kepercayaan terhadap Tuhan Yang Maha Esa. Proyek Pelestarian Dan Pengembangan Tradisi Dan Kepercayaan.

Huda, N. T. (2018). Etnomatematika Pada Bentuk Jajanan Pasar di Daerah Istimewa Yogyakarta. JNPM (Jurnal Nasional Pendidikan Matematika), 2(2), 217.

Kotler, \& Keller. (2009). Manajemen Pemasaran. Erlangga.

M, K., \& D, B. (2004). Acuan label gizi. Di dalam: Ketahanan Pangan dan Gizi di Era Otonomi Daerah dan Globalisasi. Prosiding Widya Karya Nasional Pangan Dan Gizi VIII, 431-444.

Nata, G. N. M., Suryawan, I. K. D., \& Yudiastra, P. P. (2018). Peningkatan Produktivitas Industri Rumah Tangga Jajan Tradisional Khas Gianyar. Majalah Aplikasi Ipteks NGAYAH, 9(1), 132-137.

Philipson, \& Thomas. (2005). Government Perspective: food labeling.

Ramadhan, F. H. (2017). Pemanfaatan Media Sosial Instagram Akun @Mr.Creampuff Sebagai Promosi Dalam Meningkatkan Penjualan. Jom Fisip Vol. 4 No. $2_{-}$Oktober 2017, 4(2), 1-15. 
RUASTITI, N. M. (2011). Seni Pertunjukan sebagai Pengikat Hubungan Patron-client Puri dengan Masyarakat Lingkungannya. MUDRA Jurnal Seni Budaya, 26(2), 107113.

Supraptini, Riris Nainggolan, Elsa-Elsi, \& Dharmayanti, I. (2011). Kualitas Bahan Makanan Dan Makanan Jajanan Yang Dijual Di Pasar Tradisional Di Beberapa Kota Di Indonesia. Jurnal Ekologi Kesehatan, 10(4), 208 - 218. 